\title{
A NEW ETHNOBIOLOGICAL SIMILARITY INDEX FOR THE EVALUATION OF NOVEL USE REPORTS
}

\author{
RAHMAN, I. U. ${ }^{1,2 \S}-$ HART, R. ${ }^{2}-$ AFZAL, A. ${ }^{1 *}-$ IQBAL, Z. ${ }^{1}-$ IJAZ, F. ${ }^{1}-$ ABD_ALLAH, E. F. ${ }^{3 \dagger}-$ \\ Ali, N. ${ }^{1}-$ Khan, S. M. ${ }^{4 *}$-AlqARAWI, A. A. ${ }^{3}-$ Alsubeie M. S. ${ }^{5}-$ BusSMANN, R. W. $^{6}$ \\ ${ }^{1}$ Department of Botany, Hazara University, Mansehra-21300, KP, Pakistan \\ ${ }^{2}$ William L. Brown Center, Missouri Botanical Garden \\ P. O. Box 299, St. Louis, MO 63166-0299, USA \\ ${ }^{3}$ Department of Plant Production, College of Food \& Agricultural Sciences, King Saud \\ University, P. O. Box. 2460, Riyadh 11451, Saudi Arabia \\ ${ }^{4}$ Department of Plant Sciences, Quaid-i-Azam University, Islamabad, Pakistan \\ ${ }^{5}$ Biology Department, College of Sciences, Al Imam Mohammad Ibn Saud Islamic University \\ Riyadh 11451, Saudi Arabia \\ ${ }^{6}$ Department of Ethnobotany, Institute of Botany, Ilia State University, 1 Botanical Street, 0105 \\ Tbilisi, Georgia \\ *Corresponding author \\ e-mail:aftabafzalkiani@yahoo.com; shuja60@gmail.com \\ s ORCID ID: 0000-0003-3312-7975; ${ }^{\dagger} 0000-0002-8509-8953$
}

(Received $6^{\text {th }}$ Aug 2018; accepted $7^{\text {th }}$ Nov 2018)

\begin{abstract}
Similarity Indices are widely applied in the field of ecology to measure species diversity as well as to map patterns of conservation and monitor threats to biodiversity. Among the known, Jaccard's and Sorensen's indices are the most frequently employed similarity Indices. Here, we propose a new and efficient statistical approach in the field of ethnobiology and validate its efficacy by comparing the results with predefined similarity Indices used in previous studies. The core objective was to propose a new index for quantitative ethnobiological analyses and to find out solutions for sorting the plants having similar ethnobiological uses in allied, aligned, national and global regions; as the pre-existing indices like Jaccard's and Sorensen's indices provides best estimates in the field of ecology but not in ethnobiological studies. In comparative ethnobiological studies, ethnobiologists use conventional ecological tools for evaluation of similarities and dissimilarities. Our proposed similarity index is based on the quantification of similar uses of common medicinal plants via comparing present study with previously published reports from various areas where, the author(s) have used the Sorensen's index and/or Jaccard's index. To assess the significance and validity of this newly developed index, similarities and differences in ethnomedicinal studies on medicinal plants in different regions were evaluated. Data regarding medicinal plants usage here was compared with 20 previously published studies and then analyzed through preexisting indices as well as Rahman's index to examine the novelty in the study. Our preliminary results revealed noteworthy coherence with the existing similarity indices, albeit, the new index was more efficient than the previous. Our comparison revealed, that as far as common vegetation and floral levels are concerned, the existing ecological coefficients of similarity are efficient and precise; but for similarities in the field of medicinal plant studies certain constraints are overcome by the proposed similarity index. Inferences derived from Rahman's similarity index (RSI) are as reliable as the previously known and well-established similarity indices. Further, RSI specifically targets the ethnobiological similarities, a limitation in Jaccard's and Sorensen's indices. Thus, RSI would be a useful tool/index in the assessment of rigorous quantitative ethnobiological data.
\end{abstract}

Keywords: similarity index, novel uses assessment, quantitative ethnobiology, ethnomedicine, cultural use similarities 
List of abbreviations: RSI: Rahman's similarity index; JI: Jaccard's similarity index; QS: Sorensen's similarity index; AJK: Azad Jammu and Kashmir

\section{Introduction}

\section{What are quantitative similarity indices?}

For comparing two populations, a similarity index provides a quantitatively based measurement, analogous to the application of similarity for DNA-fingerprinting (Lynch, 1990; Chuang, 2012). Similarity indices are also been widely used in ecology (Hubalek, 1982; Chao et al., 2006). Johnston (1976) investigated the characteristics of 25 similarity indices. Among these indices, the Jaccard's index (Jaccard, 1902) and Sorensen index (Sorensen, 1957) are often applied in the ecological studies. These indices are used to note the species-diversity for nature and natural protection (Higgs and Usher, 1980; Legendre and Legendre, 1998). The Jaccard's index is defined as the number of shared species divided by a total number of distinct species in two communities. The Sorensen index is the ratio of the number of shared species to the average number of total species in two communities. The definitions of the Jaccard's and Sorensen's indices are constructed on the numbers of species in two populations (Chuang, 2012).

\section{Why is an ethnobiological similarity index needed?}

It is desirable to make comparisons between floral or faunal samples taken at different times, different places, or by different techniques. Such comparisons seem profitable and take advantage of the existence of similarity indices, many of which have been developed earlier in this century. Some of these indices merely take into account the presence or absence of species in the samples, while others integrate information on the relative abundance of the species. The desirable index depends on the questions asked and the kind of data available in a given case (Wolda, 1981). In ethnobotanical studies, researchers also may wish to integrate information about the reported uses of a species. The calculation of diversity indices is a very useful tool for ethnobotanical studies, which helps researchers to ask questions and analyze data obtained through this method, besides permitting comparisons among different communities in different or similar environments (Höft et al., 1999).

Jaccard's and Sorensen's similarity indices are widely applied in the ethnobotanical studies from national and global areas, i.e. Alpine and Sub-alpine regions of Pakistan (Kayani et al., 2015), Thar Desert (Sindh), Pakistan (Yaseen et al., 2015), Abbottabad, Pakistan (Ijaz et al., 2016), Mansehra, Pakistan (Rahman et al., 2016a, b, c), Azad Kashmir, Pakistan (Ahmad et al., 2017; Amjad et al., 2017), Dindigul district, Tamilnadu, India (Faruque et al., 2018), Bandarban District of Bangladesh (Sivasankari et al., 2014), central East Shewa of Ethiopia (Feyssa, 2012), Republic of Benin (Laleye et al., 2015), Kembatta Tembaro (KT) Zone, Southern Ethiopia (Maryo et al., 2015), Brazilian Pampa Teixeira et al., 2016), but they are not amenable to comparative Ethnopharmacology (Weckerle et al., 2018).

Here, we propose a new and efficient statistical approach in the field of ethnobiology and validate its efficacy by comparing the results with predefined similarity indices used in previous studies. 


\section{Material and methods}

\section{Study area}

Manoor Valley is remote area of District Mansehra (Rahman et al., 2016a), situated on north side about $50 \mathrm{~km}$ from main Kaghan road at 'Mahandri' in the Lesser Himalayas of Pakistan (Fig. 1).

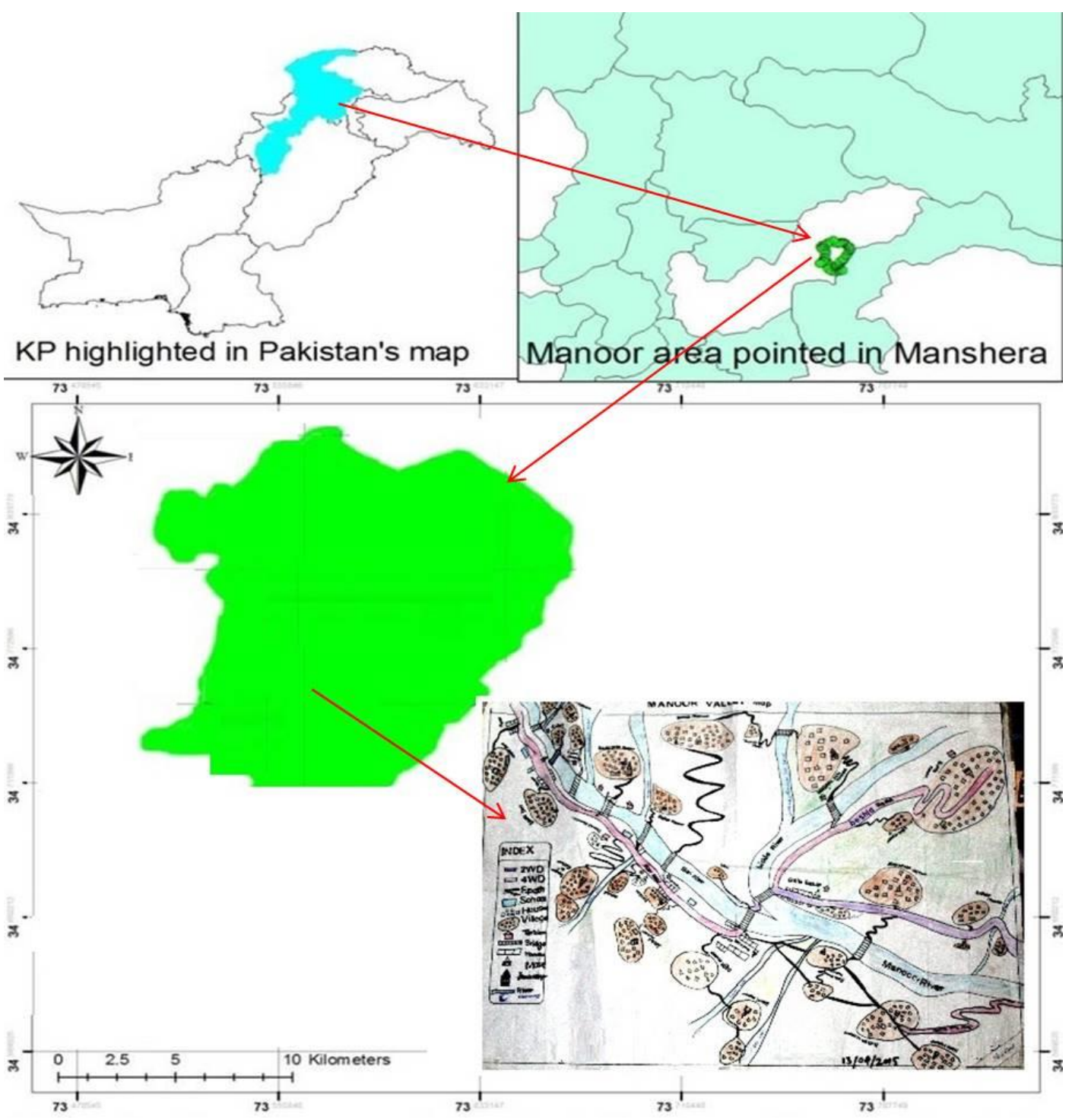

Figure 1. Map of the study area

\section{Collection and identification of medicinal plants}

Frequent field surveys were undertaken during the early, mid and late summer season of 2016. Plant specimens were collected, tagged and pressed. For botanical information, local informants and traditional healers were interviewed for cultural uses for various diseases. The plant specimens were identified with the help of available literature (Nasir and Ali, 1971-1994; Ali and Qaiser, 1995-2004) and submitted to the Herbarium, Department of Botany, Hazara University Mansehra, Pakistan (HUP). 


\section{Similarity indices}

There are a number of indices that calculate similarities in plant species and used in the field of ecology such as; Jaccard's and Sorensen's similarity indices, but no index to date has been designed for evaluation of ethnobiological similarities. So, in comparative ethnobiological studies, the ethnobiologists mostly use conventional ecological tools for evaluation of similarities and dissimilarities. We propose a similarity index named as Rahman's similarity index (RSI), based on the quantification of similar uses of common medicinal plants by comparing current study with previously published documentations from various areas. To evaluate the significance of this newly developed index and its validity in similarities and differences in ethnobiological studies of different regions, the data regarding medicinal plants usage from the current project was taken and compared with 20 previously published studies. Further, we then analyzed this data set through pre-existing indices and Rahman's index to examine the novelty in the study.

\section{Jaccard's similarity index (JI\%)}

Jaccard's similarity index (JI\%) is calculated by comparison of previously published studies from aligned, regional and at global countries by analyzing the percentages of quoted species and their medicinal uses by using the following formula:

$$
\mathrm{II}=c \times \frac{100}{a+b-c}
$$

where, $\mathrm{a}=$ number of species unique in site $\mathrm{A}, \mathrm{b}=$ number of species unique in site $\mathrm{B}$. $\mathrm{c}=$ number of species common to A and B (Jaccard, 1902; Kayani et al., 2015).

\section{Sorensen's similarity index (QS\%)}

Sorensen's similarity index (QS\%) was developed by a botanist Thorvald Sorensen and published in 1948. The comparison with previously published data collected from different regions was performed by evaluating percentages of the quoted species and their medicinal uses by applying Sorensen similarity index formula (Sorensen, 1948; Wolda, 1981).

$$
\mathrm{QS}=\frac{2 c}{a+b} \times 100
$$

where, $a=$ number of species unique in an area $A, b=$ number of species unique in an area $\mathrm{B}$ and $\mathrm{c}=$ number of species common to area $\mathrm{A}$ and $\mathrm{B}$.

\section{New ethnobiological similarity index}

Rahman's similarity index (RSI)

Rahman's similarity index (RSI) is proposed by Inayat Ur Rahman and Farhana Ijaz. RSI is calculated as "by comparison of the present study with the studies previously published from allied, regional, national and global level through the percentages of plant species analyzed and commonly cited with same cultural medicinal uses". The formula used as 


$$
\mathrm{RSI}=\frac{d}{a+b+c-d}
$$

where, "a" is the number of species unique in an area $A$, "b" is the number of species unique in an area B, "c" is the number of common species in both A and B areas and "d" is the number of common species used for similar ailment in both A and B areas. While $a \& b \neq 0$ and $c \& d \geq 0$.

To find out the percentage of common uses between two areas, the formula can be written as

$$
\mathrm{RSI}=\frac{d}{a+b+c-d} \times 100
$$

The probability was calculated (number of events divided by number of possible outcomes) by using the discrete random variables; $a=$ number of common species used for similar ailments in data set $\mathrm{A}, \mathrm{b}=$ total number of possible species in data set $\mathrm{A}$, $\mathrm{a}^{\prime}=$ number of common species used for similar ailments in data set $\mathrm{B}, \mathrm{b}^{\prime}=$ total number of possible species in data set B). To quantify the strength of evidence, we advocated 5\% significance as a standard level for concluding that there is evidence against the hypothesis tested (Dahiru, 2008).

\section{Results}

In present study, the local inhabitants and traditional healers were using 27 medicinal plant species belonging to 19 families for treating 42 different diseases. Traditional medicinal uses of plants mentioned in Table 1 are compared with 20 published ethnomedicinal documentations of allied, regional, national and at global level Table 2.

\section{Critical comparison of JI and QS with RSI}

Comparative analysis of the present study and previously published investigations reveals the similarity index of 27 reported medicinal plants ranging from $0 \%$ to $15.69 \%$ (JI\%), $0 \%$ to $27.12 \%$ (QS\%) and $0 \%$ to $6.78 \%$ (RSI\%) as shown in Table 2. The analytical approach of Jaccard's and Sorensen's similarity indices both determines only the common floral similarity by comparison of a case study with previous documentations. They don't address the common plants with similar use(s) (Table 2). The Jaccard's index derives similarity of community ecology but now it is frequently used for assessing the similarity of pharmacopoeias and medical floras. Imagine two datasets (medicinal flora) with sample $a=$ 100 and sample $b=100$ and an overlap of similar plant species is $c=50$; out of these, 25 plants are with similar usage. While JI delivers a similarity index of $20 \%$, the actual overlap is $25 \%$ (plant species with similar usage). When we employ QS on the same datasets, it delivers a similarity index of $33 \%$, the actual overlap is $25 \%$ (plant species with similar usage). While, the proposed similarity index (RSI) shows the cultural similarities between ethnic communities of different areas by calculating particular plant species, same medicinal usage. Imagine same datasets (medicinal flora) with sample $a=100$ and sample $b$ $=100$ and an overlap of plant species is $\mathrm{c}=50$ but out of these, 25 plants are with similar usage $\mathrm{d}=25$ for RSI. It delivers a similarity index of $25 \%$ which is the actual overlap (plant species with similar usage). Upon comparison with pre-existing similarity indices (JI and QS), new medicinal use reports of plant species are more accurately determined by the proposed similarity index (RSI). 
Cross-cultural analysis of the reported species assessed through the newly developed similarity index (RSI) revealed new medicinal uses for Ajuga integrifolia, Dysphania ambrosioides, Cichorium intybus, Convolvulus arvensis, Indigofera heterantha, Malva parviflora, Plantago major, Medicago sativa, Portulaca oleracea, Punica granatum, Taraxacum officinale, Trachyspermum amii, Trifolium repens, Xanthium strumarium and Zanthoxylum armatum for the first time, but not indicated by the JI or QS indices. These results indicate that as far as common vegetation and the floral levels are concerned, these ecological similarity coefficients are accurate and precise but for medicinal similarities, both pose limitations. To overcome these limitations, we propose this new index, which could address the similarity between two regions/sites on the basis of common plant/animal species with respect to their uses.

Table 1. Randomly selected medicinal plants from the first author PhD study, a supposition for comparison with other documentations from different regions for similarities to show differences in results of two well-known indices with our newly developed one, documentations of shared species are mentioned in the column 'literature comparison'

\begin{tabular}{|c|c|c|c|}
\hline S. No & Botanical name & Medicinal uses & Literature comparison \\
\hline 1 & $\begin{array}{c}\text { Ajuga integrifolia Buch.-Ham. ex D. } \\
\text { Don. }\end{array}$ & Diabetes & 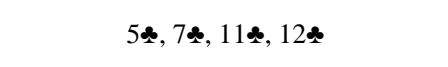 \\
\hline 2 & Bauhinia variegata $\mathrm{L}$. & Fatness & $4 \boldsymbol{\mu}, 8 \boldsymbol{\mu}, 14 \boldsymbol{\mu}, 18 \boldsymbol{\kappa}$ \\
\hline 3 & Cannabis sativa $\mathrm{L}$. & Warmness, insomnia & 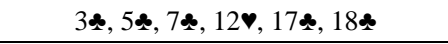 \\
\hline 4 & $\begin{array}{l}\text { Dysphania ambrosioides (L.) } \\
\text { Mosyakin \& Clemants }\end{array}$ & Fever & 52 \\
\hline 5 & Cichorium intybus L. & Typhoid fever & $3 \boldsymbol{\bullet}, 12 \boldsymbol{\varphi}$ \\
\hline 6 & Convolvulus arvensis $\mathrm{L}$. & Diarrhoea, dysentery & 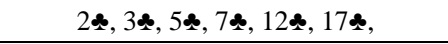 \\
\hline 7 & Indigofera heterantha Wall. ex Brandis & Diuretic & $2 \boldsymbol{k}, 4 \boldsymbol{k}, 12 \boldsymbol{k}, 14 \boldsymbol{s}$ \\
\hline 8 & Justicia adhatoda L. & Throat infection, cough & $3 \boldsymbol{\bullet}, 4 \boldsymbol{\bullet}, 14 \boldsymbol{\bullet}, 20 \boldsymbol{\bullet}$ \\
\hline 9 & Malva parviflora $\mathrm{L}$. & Gas trouble & 17 \\
\hline 10 & Medicago sativa $\mathrm{L}$. & Gas trouble & \\
\hline 11 & Mentha longifolia (L.) Huds. & Abdominal pain, gas trouble & $2 \bullet, 5 \boldsymbol{\bullet}, 6 \boldsymbol{\bullet}, 19 \boldsymbol{\bullet}$ \\
\hline 12 & Mentha royleana Benth. & Diarrhoea, vomiting & $2 \bullet, 12 \bullet$ \\
\hline 13 & Oxalis corniculata $\mathrm{L}$. & Vitamin C deficiency, mouth smell & $3 \mathbf{\bullet}, 5 \boldsymbol{\bullet}, 12 \boldsymbol{\bullet}, 14 \boldsymbol{\bullet}, 16 \boldsymbol{\bullet}$ \\
\hline 14 & Plantago major $\mathrm{L}$. & Diarrhoea, fatness & 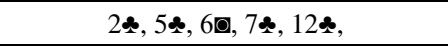 \\
\hline 15 & Polygonum plebeium R. Br. & Cough & $2 \boldsymbol{k}, 5 \boldsymbol{k}, 14 \boldsymbol{\varphi}$ \\
\hline 16 & Portulaca oleracea L. & Diuretic & 12 \\
\hline 17 & Punica granatum $\mathrm{L}$. & Gas troubles, indigestion & 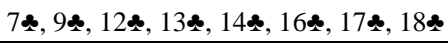 \\
\hline 18 & Ricinus communis $\mathrm{L}$. & Constipation & 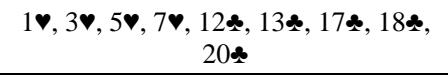 \\
\hline 19 & Salvia moorcroftiana Wall. ex Benth. & Cough, diarrhoea & $2 \boldsymbol{s}, 12,16$ \\
\hline 20 & Silybum marianum (L.) Gaertn. & Liver problems & $1 \bullet, 3 \bullet$ \\
\hline 21 & Taraxacum officinale F.H. Wigg. & Diabetes & $1 \boldsymbol{2}, 2 \boldsymbol{s}, 6 \boldsymbol{s}$ \\
\hline 22 & Trachyspermum ammii (L.) Sprague & Diuretic, kidney stone removal & 72 \\
\hline 23 & Trifolium repens $\mathrm{L}$. & Fever & 2 \\
\hline 24 & Verbascum thapsus L. & Diarrhoea & $1 \boldsymbol{\bullet}, 2 \boldsymbol{\bullet}, 3 \boldsymbol{\bullet}, 5 \boldsymbol{\bullet}, 7 \boldsymbol{\bullet}, 14 \boldsymbol{\bullet}$ \\
\hline 25 & Vitex negundo L. & $\begin{array}{l}\text { Indigestion, stomach-ache, gas } \\
\text { troubles }\end{array}$ & $9 \mathbf{k}, 13 \boldsymbol{k}, 14 \boldsymbol{\bullet}, 20 \boldsymbol{\bullet}$ \\
\hline 26 & Xanthium strumarium L. & Diuretic, kidney stone removal & $5 \boldsymbol{\omega}, 12 \boldsymbol{k}, 14 \boldsymbol{\omega}$ \\
\hline 27 & Zanthoxylum armatum DC. & Abdominal pain, indigestion & 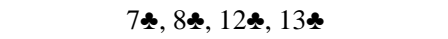 \\
\hline
\end{tabular}

$\boldsymbol{\varphi}=$ Similar uses reported and $\boldsymbol{\omega}=$ Dissimilar uses reported

1 = Jamal et al. (2012); 2 = Khan et al. (2013); 3 = Qureshi et al. (2008); 4 = Jan et al. (2011); $5=$ Matin et al. (2001); $6=$ UmeUmmara et al. (2013); 7 = Abbasi et al. (2013); 8 = Ahmad et al. (2012); 9 = Ajaib and Khan (2014); 10= Ahmad et al. (2009); 11 = Tariq et al. (2014); $12=$ Akhtar et al. (2013); $13=$ Rashid et al. (2015); $14=$ Ijaz et al. (2016); 15= Bano et al. (2014); 16= Ahmad and Pieroni (2016); $17=$ Ullah et al. (2014); $18=$ Kichu et al. (2015); $19=$ Ozdemir and Alpinar (2015); $20=$ Kadir et al. (2014) 


\section{Discussion}

In present study, 27 plant species belonging to 19 families were reported by the local informants for 42 various health issues. The ethnomedicinal uses reported in the present study (Table 1) were compared with 20 published ethnomedicinal studies from allied, regional, national as well as at global level (Table 2). Comparative analysis of present study with previous documentations revealed that the similarity index of 27 reported medicinal plants ranged from $0 \%$ to $15.59 \%$ (JI) and $0 \%$ to $27.12 \%$ (QS) (Fig. 2). Highest degree of similarity index was found with studies conducted by Qureshi et al. (2008); Akhtar et al. (2013); Ijaz et al. (2016), Matin et al. (2001) and Khan et al. (2013) with JI $(15.69 \%, 15.22 \%, 13.89 \%, 10.78 \%$ and $10.10 \%)$ respectively and QS $(27.12 \%, 26.42 \%, 24.39 \%, 19.47 \%$ and $18.35 \%)$ respectively. Furthermore, three more international documentations having the common species with the present study, due to which JI and QS shows similarity percentage with the study area, but interesting thing is that all of them were used for different medicinal purposes which clearly means that Jaccard's and Sorensen's similarity indices both targets only the common medicinal plant species in both areas but not its common medicinal uses (Table 1). Table 1 shows three different values which are of species enlisted only in the study area, common species with similar uses and common species with dissimilar uses. But JI and QS shows the results by combining both common species with similar uses and common species with dissimilar uses in similarity. This simply reveals that either the common plant species is similar or different in medicinal use but it is in similarity by JI and QS. In comparison, we found Jaccard's similarity index and Sorensen's similarity index value 0\% with 3 studies from Siran Valley, (Mansehra), Pakistan (Ahmad et al., 2009), Deosai Plateau, Gilgit Baltistan, Pakistan (Bano et al., 2014) and Aladaglar, NigdeTurkey (Ozdemir and Alpınar, 2015). But in this case, no single common plant species has been found that is why JI and QS also showed 0\% similarity (Fig. 2).

Table 2. Comparison of the present study with previous studies at regional, neighboring and global level

\begin{tabular}{c|c|c|c|c|c|c|c|c|c|c|c}
\hline Study area & NRSAA & TSCBA & SEOAA & SEOOA & CSSU & CSDU & JI\% & QS\% & RSI\% & Citation & $\begin{array}{c}\text { Sign. } \\
(\mathbf{5 \%})\end{array}$ \\
\hline $\begin{array}{c}\text { Kaghan Valley, } \\
\text { Pakistan }\end{array}$ & 30 & 4 & 26 & 23 & 2 & 2 & 8.70 & 16.00 & 4.00 & $\begin{array}{c}\text { Jamal et al. } \\
(2012)\end{array}$ & 0.49 \\
\hline $\begin{array}{c}\text { Naran Valley, } \\
\text { Pakistan }\end{array}$ & 101 & 10 & 91 & 17 & 2 & 8 & 10.10 & 18.35 & 1.83 & $\begin{array}{c}\text { Khan et al. } \\
(2013)\end{array}$ & 0.15 \\
\hline $\begin{array}{c}\text { Abbottabad, } \\
\text { Pakistan }\end{array}$ & 47 & 8 & 39 & 19 & 4 & 4 & 15.69 & 27.12 & 6.78 & $\begin{array}{c}\text { Qureshi et al. } \\
(2008)\end{array}$ & 1.26 \\
\hline $\begin{array}{c}\text { Kaghan Valley, } \\
\text { Pakistan }\end{array}$ & 75 & 3 & 72 & 24 & 1 & 2 & 3.19 & 6.19 & 1.03 & $\begin{array}{c}\text { Jan et al. } \\
(2011)\end{array}$ & 0.05 \\
\hline $\begin{array}{c}\text { Shogran } \\
\text { Valley, } \\
\text { Pakistan }\end{array}$ & 107 & 11 & 96 & 16 & 2 & 9 & 10.78 & 19.47 & 1.77 & $\begin{array}{c}\text { Matin et al. } \\
(2001)\end{array}$ & 0.14 \\
\hline $\begin{array}{c}\text { Shogran } \\
\text { Valley, } \\
\text { Pakistan }\end{array}$ & 50 & 2 & 48 & 25 & 1 & 1 & 2.78 & 5.41 & 1.35 & $\begin{array}{c}\text { Ummara et al. } \\
(2013)\end{array}$ & 0.07 \\
\hline $\begin{array}{c}\text { Himalaya, } \\
\text { Pakistan }\end{array}$ & 89 & 9 & 80 & 18 & 2 & 7 & 10.00 & 18.18 & 2.02 & $\begin{array}{c}\text { Abbasi et al. } \\
(2013)\end{array}$ & 0.17 \\
\hline $\begin{array}{c}\text { Kotli, AJK, } \\
\text { Pakistan }\end{array}$ & 112 & 2 & 110 & 25 & 0 & 2 & 1.49 & 2.94 & 0.00 & $\begin{array}{c}\text { Ahmad et al. } \\
(2012)\end{array}$ & 0.00 \\
\hline $\begin{array}{c}\text { Kotli, AJK, } \\
\text { Pakistan }\end{array}$ & 50 & 2 & 48 & 25 & 0 & 2 & 2.78 & 5.41 & 0.00 & $\begin{array}{c}\text { Ajaib and } \\
\text { Khan (2014) }\end{array}$ & 0.00 \\
\hline
\end{tabular}




\begin{tabular}{|c|c|c|c|c|c|c|c|c|c|c|c|}
\hline $\begin{array}{l}\text { Siran Valley, } \\
\text { Pakistan }\end{array}$ & 143 & 0 & 143 & 27 & 0 & 0 & 0.00 & 0.00 & 0.00 & $\begin{array}{c}\text { Ahmad et al. } \\
(2009)\end{array}$ & 0.00 \\
\hline $\begin{array}{l}\text { Nathiagali, } \\
\text { Pakistan }\end{array}$ & 31 & 1 & 30 & 26 & 0 & 1 & 1.79 & 3.51 & 0.00 & $\begin{array}{l}\text { Tariq et al. } \\
\text { (2014) }\end{array}$ & 0.00 \\
\hline $\begin{array}{l}\text { Swat, North } \\
\text { Pakistan }\end{array}$ & 106 & 14 & 92 & 13 & 3 & 11 & 15.22 & 26.42 & 2.83 & $\begin{array}{c}\text { Akhtar et al. } \\
(2013)\end{array}$ & 0.31 \\
\hline AJK, Pakistan & 73 & 4 & 69 & 23 & 0 & 4 & 4.49 & 8.60 & 0.00 & $\begin{array}{c}\text { Rashid et al. } \\
\text { (2015) }\end{array}$ & 0.00 \\
\hline $\begin{array}{l}\text { Sarban Hills, } \\
\text { Abbottabad, } \\
\text { Pakistan }\end{array}$ & 74 & 10 & 64 & 17 & 5 & 5 & 13.89 & 24.39 & 6.10 & $\begin{array}{l}\text { Ijaz et al. } \\
\text { (2016) }\end{array}$ & 1.25 \\
\hline $\begin{array}{c}\text { Deosai Plateau, } \\
\text { Gilgit } \\
\text { Baltistan, } \\
\text { Pakistan } \\
\end{array}$ & 50 & 0 & 50 & 27 & 0 & 0 & 0.00 & 0.00 & 0.00 & $\begin{array}{l}\text { Bano et al. } \\
\text { (2014) }\end{array}$ & 0.00 \\
\hline $\begin{array}{c}\text { Thakt-e- } \\
\text { Sulaiman Hills, } \\
\text { Pakistan }\end{array}$ & 51 & 3 & 48 & 24 & 0 & 3 & 4.29 & 8.22 & 0.00 & $\begin{array}{l}\text { Ahmad and } \\
\text { Pieroni } \\
(2016) \\
\end{array}$ & 0.00 \\
\hline $\begin{array}{c}\text { Lakki Marwat, } \\
\text { Pakistan }\end{array}$ & 72 & 5 & 67 & 22 & 0 & 5 & 5.88 & 11.11 & 0.00 & $\begin{array}{c}\text { Ullah et al. } \\
\text { (2014) }\end{array}$ & 0.00 \\
\hline $\begin{array}{c}\text { Chungtia } \\
\text { village, } \\
\text { Nagaland, } \\
\text { India } \\
\end{array}$ & 135 & 3 & 132 & 24 & 0 & 3 & 2.65 & 5.16 & 0.00 & $\begin{array}{l}\text { Kichu et al. } \\
\text { (2015) }\end{array}$ & 0.00 \\
\hline $\begin{array}{c}\text { Aladaglar, } \\
\text { Nigde-Turkey }\end{array}$ & 110 & 0 & 110 & 27 & 0 & 0 & 0.00 & 0.00 & 0.00 & $\begin{array}{l}\text { Ozdemir and } \\
\text { Alpinar } \\
(2015)\end{array}$ & 0.00 \\
\hline $\begin{array}{l}\text { Thanchi, } \\
\text { Bandarban } \\
\text { Hill, } \\
\text { Bangladesh }\end{array}$ & 84 & 3 & 81 & 24 & 1 & 2 & 2.91 & 5.66 & 0.94 & $\begin{array}{l}\text { Kadir et al. } \\
\text { (2014) }\end{array}$ & 0.04 \\
\hline
\end{tabular}

NRSAA: Number of recorded plants species of aligned areas, TSCBA: Total species common in both area, SEOAA: Species enlisted only in aligned areas, SEOOA: Species enlisted only in our study area, CSSU: Common species with similar uses, CSDU: Common species with dissimilar uses, JI: Jaccard's similarity index, QS: Sorrenson's similarity index, RSI: Rahman's similarity index, Sign.: Significance level

\section{Applications of Rahman's similarity index (RSI)}

The similarities and differences in ethnomedicinal studies seem to target the importance of traditional knowledge on medicinal plants in different regions (Ijaz et al., 2016). The proposed similarity index (RSI) shows the cultural similarities between ethnic communities of different areas by calculating particular plant species, same medicinal usage. Traditional medicinal uses of plants mentioned in Table 1 are compared with 20 published ethnomedicinal documentations of allied, regional, national and at global level (Table 2). Review of the literature indicates the medicinal similarity index uses ranges from 0\% (Ahmad et al., 2009, 2012; Ajaib and Khan, 2014; Bano et al., 2014; Tariq et al., 2014; Ullah et al., 2014; Ozdemir and Alpınar, 2015; Rashid et al., 2015; Kichu et al., 2015; Ahmad and Pieroni, 2016) to 6.78\% (Qureshi et al., 2008). The highest degree of similarity index of the present study was found with a study conducted in Abbottabad, Pakistan by Qureshi et al. (2008) with RSI $=6.78 \%$ (Fig. 2). In comparison, we found RSI value $0 \%$ with 10 previous studies and out of these seven studies had common plant species but no single common plant species has been cited for common medicinal use(s) that is why RSI showed $0 \%$ similarity (Fig. 2). These results indicate that the new index (RSI) could address the similarity between two regions/sites on the basis of common plant/animal species with respect to their uses. Medicinal uses comparative analysis reveals that maximum variation in RSI might be due to cultural/ethnic or traditional differences between the current study area and previously documented studies in allied, regional, national and global levels. Distance 
between study area and other regions also support the variation in results as it directly correlates the vegetation of an area due to the differences in their edaphic factors (Coughenour and Ellis, 1993; Witkowski and O'Connor, 1996) and physiographic because each area has specific surface features and their form (Barnes et al., 1998). RSI shows the cultural similarities between ethnic communities of different areas by calculating particular plant species similar medicinal usage. RSI focuses on similar uses of common medicinal plants (Table 2 and Fig. 2). Upon comparison with both the similarity indices, new medicinal use reports of plant species are more accurately determined by the proposed similarity index (Fig. 2).

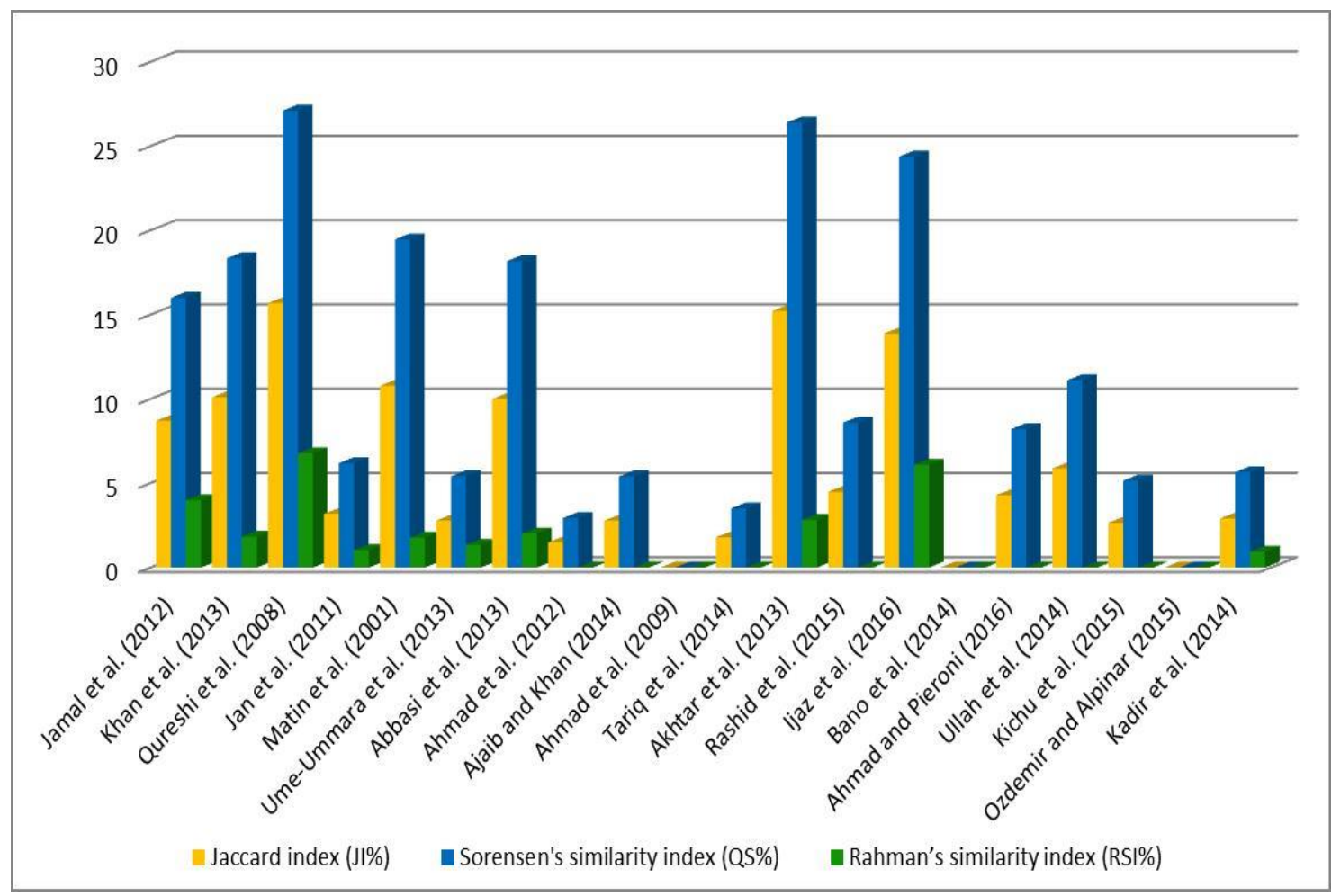

Figure 2. Comparison of the case study with previous studies at regional, national and global level through Jaccard's, Sorensen's, Rahman's similarity indices

\section{Similarity indices and significance level}

Comparative analyses of the present study with Matin et al. (2001) revealed that in total 27 reported medicinal plants; two species were common in medicinal usage to both areas. The JI is consequently $10.78 \%$ and QS is $19.47 \%$, but newly proposed index (RSI) showed $1.77 \%$ similarity. Whereas the results of RSI are also supported by significance test (5\%), as the level of significance between present study and Matin et al. (2001) indicating the significance value of 0.13 . We found RSI value of $0 \%$ while comparing with previously done 10 ethnobiological studies (Ahmad et al., 2009, 2012; Ajaib and Khan, 2014; Bano et al., 2014; Tariq et al., 2014; Ullah et al., 2014; Ozdemir and Alpınar, 2015; Rashid et al., 2015; Kichu et al., 2015; Ahmad and Pieroni, 2016), and out of these 7 studies had common plant species but no single common plant species has been cited for common medicinal use(s) that is why RSI showed $0 \%$ 
similarity. The level of significance also strongly supports these results by indicating the highest level of significance $(0.00 \%)$ (Table 2). The threshold level of significance for RSI is $>1 \%$ (more than 1), as this is the border line of significance level at $5 \%$ $(\mathrm{p}=0.05)$. Furthermore, with 2 previous studies (Ijaz et al., 2016; Qureshi et al., 2008) maximum RSI (6.1\% and 6.78\%) was found and following these results the significance level was also increased $(1.25 \%$ and $1.26 \%)$ respectively in comparison with other studies. Our results are in accordance with Goodall (1966) who reported that a lower value of the similarity index may often correspond with a less probable degree of similarity and vice versa.

\section{Conclusion, novelty and future impact}

After analytical comparison, some new medicinal uses of Ajuga integrifolia, Bauhinia variegata, Dysphania ambrosioides, Convolvulus arvensis, Indigofera heterantha, Malva parviflora, Plantago major, Salvia moorcroftiana, Taraxacum officinale, Xanthium strumarium, Medicago sativa, Portulaca oleracea, Punica granatum, Trachyspermum ammii, Trifolium repens and Zanthoxylum armatum were recorded for the first time for the current reported medicinal uses from the study area. These novel/new medicinal use reports of plant species were pinpointed by the newly developed similarity index (RSI) but not indicated by the JI or QS indices. Inferences derived from RSI are reliable and upon comparison can lead to novel findings and new medicinal use reports of plant species more accurately. Further, RSI specifically targets the ethnobiological similarities and would be a useful tool/index for future studies in the assessment of rigorous quantitative ethnobiological data.

Acknowledgements. First author would like to thank Higher Education Commission (HEC), Pakistan for granting scholarship under International Research Support Initiative Program (IRSIP) to conduct a research work at Missouri Botanical Garden, USA. The authors gratefully acknowledge Dr. Robbie Hart (Missouri Botanical Garden, P. O. Box 299, St. Louis, MO 63166-0299, USA) for his confirmatory input in the index. We are thankful to Dr. Shahzad, Head Department of Mathematics, Hazara University Mansehra, Pakistan as well for. helping us in statistical work. The authors would like to extend their sincere appreciation to the Deanship of Scientific Research at King Saud University for its funding to the Research Group number (RG-1435-014).

Author contributions. IUR designed and conceived the study. IUR and FI developed the formula, gathered relevant literature and analyzed the data. IUR wrote the manuscript and NA helped in writing. AA, ZI and RH supervised the work, RH and SMK helped in the data analysis, RBU, EFA and AAA critically reviewed the manuscript. IUR and NA revised the manuscript, MSA helped in revision. All the authors have read and approved the final manuscript.

Ethical approval. This ethnomedicinal study was approved by the "Advanced Studies Research Board, Hazara University Mansehra, Pakistan”. A semi-structured questionnaire (written consent) was developed and filled during interviews with local informants and traditional healers.

Conflict of interests. The authors declare that the research was conducted in the absence of any commercial or financial relationships that could be construed as a potential conflict of interests.

\section{REFERENCES}

[1] Abbasi, A. M., Khan, S. M., Ahmad, M., Khan, M. A., Quave, C. L., Pieroni, A. (2013): Botanical ethnoveterinary therapies in three districts of the Lesser Himalayas of Pakistan. - J. Ethnobiol. Ethnomed. 9: 84. 
[2] Ahmad, H., Khan, S. M., Ghafoor, S., Ali, N. (2009): Ethnobotanical study of Upper Siran. - J. Herbs Spices Med. Plants 15: 86-97.

[3] Ahmad, K., Pieroni, A. (2016): Folk knowledge of wild food plants among the tribal communities of Thakhte-Sulaiman Hills, North-West Pakistan. - J. Ethnobiol. Ethnomed. 12: 17 .

[4] Ahmad, K. S., Kayani, W. K., Hameed, M., Ahmad, F., Nawaz, T. (2012): Floristic diversity and ethnobotany of Senhsa, District Kotli, Azad Jammu \& Kashmir (Pakistan). - Pak. J. Bot. 44: 195-201.

[5] Ahmad, K. S., Hamid, A., Nawaz, F., Hameed, M., Ahmad, F., Deng, J., Mahroof, S. (2017): Ethnopharmacological studies of indigenous plants in Kel village, Neelum Valley, Azad Kashmir, Pakistan. - J. Ethnobiol. Ethnomed. 13(1): 68.

[6] Ajaib, M., Khan, Z. (2014): Ethnobotanical studies of useful trees of District Kotli, Azad Jammu and Kashmir. - Biologia 60: 63-71.

[7] Akhtar, N., Rashid, A., Murad, W., Bergmeier, E. (2013): Diversity and use of ethnomedicinal plants in the region of Swat, North Pakistan. - J. Ethnobiol. Ethnomed. 9: 25.

[8] Ali, S. I., Qaiser, M. (1995-2004). Flora of Pakistan. - Pakistan Agricultural Research Council, Islamabad.

[9] Amjad, M. S., faisal Qaeem, M., Ahmad, I., Khan, S. U., Chaudhari, S. K., Malik, N. Z., Khan, A. M. (2017): Descriptive study of plant resources in the context of the ethnomedicinal relevance of indigenous flora: A case study from Toli Peer National Park, Azad Jammu and Kashmir, Pakistan. - PloS One 12(2): e0171896.

[10] Bano, A., Ahmad, M., Zafar, M., Sultana, S., Rashid, S., Khan, M. A. (2014): Ethnomedicinal knowledge of the most commonly used plants from Deosai Plateau, Western Himalayas, Gilgit Baltistan, Pakistan. - J. Ethnopharmacol. 155: 1046-1052.

[11] Barnes, B. V., Zak, D. R., Denton, S. R., Spurr, S. H. (1998): Forest Ecology, $4^{\text {th }}$ Ed. John Wiley \& Sons, New York.

[12] Chao, A., Chazdon, R. L., Colwell, R. K., Shen, T. J. (2006): Abundance-based similarity indices and their estimation when there are unseen species in samples. - Biometrics 62: 361-371.

[13] Chuang, C. (2012): Estimation of similarity indices via two-sample jackknife procedure. - J. Appl. Sci. Eng. 15(3): 301310.

[14] Coughenour, M. B., Ellis, J. E. (1993): Climate and landscape control of woody vegetation in a dry tropical ecosystem, Turkana District, Kenya. - J. Biogeogr. 20: 283398.

[15] Dahiru, T. (2008): P - VALUE. A true test of statistical significance? A cautionary note. - Ann. Ib. Postgrad. Med. 6: 21-26.

[16] Faruque, M. O., Uddin, S. B., Barlow, J. W., Hu, X. (2018): Quantitative ethnobotany of medicinal plants used by indigenous communities in the Bandarban District of Bangladesh. - Front. Pharmacol. 9: 40.

[17] Feyssa, D. H. (2012): Comparative analysis of indigenous knowledge on use and management of wild edible plants: The case of central East Shewa of Ethiopia. Ethnobotany 10: 287-304.

[18] Goodall, D. W. (1966): A new similarity index based on probability. - Biometrics 22(4): 882-907.

[19] Higgs, A. J., Usher, M. B. (1980): Should nature reserves be large or small? - Nature 285: 568-569.

[20] Höft, M., Barik, S. K., Lykke, A. M. (1999): Quantitative Ethnobotany. Applications of Multivariate and Statistical Analyses in Ethnobotany. - People and Plants Initiative, Working Papers, 6. UNESCO, Paris.

[21] Hubalek, Z. (1982): Coefficients of Association and similarity, based on binary (presence-absence) data: an evaluation. - Biol. Rev. 57: 669-689. 
[22] Ijaz, F., Iqbal, Z., Rahman, I. U., Alam, J., Khan, S. M., Shah, G. M., Khan, K., Afzal, A. (2016): Investigation of traditional medicinal floral knowledge of Sarban Hills, Abbottabad, KP, Pakistan. - J. Ethnopharmacol. 179: 208-233.

[23] Jaccard, P. (1902): Lois De Distribution Florale Dans La Zone Alpine. - Bulletin Societe Vau-doise Sciences Naturelles 38: 67-130.

[24] Jamal, Z., Ahmad, M., Zafar, M., Sultana, S., Khan, M. A., Shah, G. M. (2012): Medicinal plants used in folk recipes by the local communities of Kaghan valley, Mansehra, Pakistan. - Indian J. Tradit. Know. 11: 634-639.

[25] Jan, G., Khan, M. A., Khan, A., Jan, F., Khan, R., Ahmad, M., Atta-Ur-Rehman, Danish, M., Asif, M., Khan, S., Zafar, M. (2011): An ethnobotanical survey on fuel wood and timber plant species of Kaghan Valley, Khyber Pakhtoonkhwa Province, Pakistan. - Afr. J. Biotechnol. 10: 19075-19083.

[26] Johnston, J. W. (1976): Similarity Indices I: What Do They Measure? Prepared for Nuclear Regulatory Commission. - Battelle Pacific Northwest Laboratories Richland, Washington.

[27] Kadir, M. F., Sayeed, M. S. B., Setu, N. I., Mostafa, A., Mia, M. M. K. (2014): Ethnopharmacological survey of medicinal plants used by traditional health practitioners in Thanchi, Bandarban Hill Tracts, Bangladesh. - J. Ethnopharmacol. 155: 495-508.

[28] Kayani, S., Ahmad, M., Sultana, S., Shinwari, Z. K., Zafar, M., Yaseen, G., Bibi, T. (2015): Ethnobotany of medicinal plants among the communities of Alpine and Subalpine regions of Pakistan. - J. Ethnopharmacol. 164: 186-202.

[29] Khan, S. M., Page, S., Ahmad, H., Shaheen, H., Ullah, Z., Ahmad, M., Harper, D. M. (2013): Medicinal flora and ethnoecological knowledge in the Naran Valley, Western Himalaya, Pakistan. - J. Ethnobiol. Ethnomed. 9: 4.

[30] Kichu, M., Malewska, T., Akter, K., Imchen, I., Harrington, D., Kohen, J., Vemulpad, S. R., Jamie, J. F. (2015): An ethnobotanical study of medicinal plants of Chungtia village, Nagaland, India. - J. Ethnopharmacol. 166: 5-17.

[31] Laleye, F. O. A., Mensah, S., Assogbadjo, A. E., Ahissou, H. (2015): Diversity, knowledge, and use of plants in traditional treatment of diabetes in the Republic of Benin. - Ethnobotany Res. Applications 14: 231-257.

[32] Legendre, P., Legendre, L. (1998): Numerical Ecology, 2nd Ed. - Elsevier Science.

[33] Lynch, M. (1990): The similarity index and DNA fingerprinting. - Mol. Biol. Evol. 7: 478-484.

[34] Maryo, M., Nemomissa, S., Bekele, T. (2015): An ethnobotanical study of medicinal plants of the Kembatta ethnic group in Enset-based agricultural landscape of Kembatta Tembaro (KT) Zone, Southern Ethiopia. - Asian J. Plant Sci. Res. 5(7): 42-61.

[35] Matin, A., Khan, M. A., Ashraf, M., Qureshi, R. A. (2001): Traditional uses of herbs, shrubs and trees of Shugran Valley, Mansehra, Pakistan. - Pak. J. Biol. Sci. 4: 11011107.

[36] Nasir, E., Ali, S. I. (1971-1994). Flora of Pakistan. - Pakistan Agriculture Research Council, Islamabad.

[37] Ozdemir, E., Alpınar, K. (2015): An ethnobotanical survey of medicinal plants in western part of central Taurus Mountains: Aladaglar (Nigde - Turkey). - J. Ethnopharmacol. 166: 53-65.

[38] Qureshi, S. J., Khan, M. A., Ahmad, M. (2008): A survey of useful medicinal plants of Abbottabad in Northern Pakistan. - Trakia J. Sci. 6: 39-51.

[39] Rahman, I. U., Ijaz, F., Afzal, A., Iqbal, Z., Ali, N., Khan, S. M. (2016a). Contributions to the phytotherapies of digestive disorders. Traditional knowledge and cultural drivers of Manoor Valley, Northern Pakistan. - J. Ethnopharmacol. 192: 30-52.

[40] Rahman, I. U., Ijaz, F., Iqbal, Z., Afzal, A., Ali, N., Afzal, M., Khan, M. A., Muhammad, S., Qadir, G., Asif, M. (2016b). A novel survey of the ethnomedicinal knowledge of dental problems in Manoor Valley (Northern Himalaya), Pakistan. - J. Ethnopharmacol. 194C: 877-894. 
[41] Rahman, I. U., Ijaz, F., Iqbal, Z., Afzal, A., Ali, N., Khan, M. A., Afzal, M., Muhammad, S., Qadir, G., Asif, M. (2016c). Graphical dataset on important medicinal plants used for curing dental issues in Manoor Valley, Mansehra, Pakistan. - Data in Brief 9: 1028-1033.

[42] Rashid, S., Ahmad, M., Zafar, M., Sultana, S., Ayub, M., Khan, M. A., Yaseen, G. (2015): Ethnobotanical survey of medicinally important shrubs and trees of Himalayan region of Azad Jammu and Kashmir, Pakistan. - J. Ethnopharmacol. 166: 140-151.

[43] Sivasankari, B., Anandharaj, M., Gunasekaran, P. (2014): An ethnobotanical study of indigenous knowledge on medicinal plants used by the village peoples of Thoppampatti, Dindigul district, Tamilnadu, India. - J. Ethnopharmacol. 153: 408-423.

[44] Sorensen, T. (1957): A method of establishing groups of equal amplitude in plant sociology based on similarity of species and its application to analyses of the vegetation on Danish commons. - Biologiske Skrifter/Kongelige Danske Videnskabernes Selskab 5: 1-34.

[45] Sorensen, T. A. (1948): A method of establishing groups of equal amplitude in plant sociology based on similarity of species content, and its application to analyses of the vegetation on Danish commons. - K dan Vidensk Selsk Biol Skr 5: 1-34.

[46] Tariq, A., Adnan, M., AbdElsalam, N. M., Fouad, H., Hussain, K., Ullah, R., Ullah, A. (2014): Richness and cover of nontimber economic plants along altitude in temperate $\begin{array}{lllllll}\text { Himalayan forest-use types. } & - & \text { Sci. World J. } & \text { 748490: } & 10\end{array}$ http://dx.doi.org/10.1155/2014/748490.

[47] Teixeira, M. P., Cruz, L., Franco, J. L., Vieira, R. B., Stefenon, V. M. (2016): Ethnobotany and antioxidant evaluation of commercialized medicinal plants from the Brazilian Pampa. - Acta Bot. Bras. 30(1): 47-59.

[48] Ullah, S., Khan, M. R., Shah, N. A., Shah, S. A., Majid, M., Farooq, M. A. (2014): Ethnomedicinal plant use value in the Lakki Marwat District of Pakistan. - J. Ethnopharmacol. 158: 412-422.

[49] Ume-Ummara, Bokhari, T. Z., Altaf, A., Younis, U., Dasti, A. A. (2013): Pharmacological study of Shogran Valley Flora, Pakistan. - Int. J. Sci. Eng. Res. 4: 9.

[50] Weckerle, C. S., de Boer, H. J., Puri, R. K., Andel, T. Y., Bussmann, R. W., Leonti, M. (2018): Recommended standards for conducting and reporting ethnopharmacological field studies. - J. Ethnopharmacol. 210: 125-132.

[51] Witkowski, E., O’Connor, T. (1996): Topo-edaphic, floristic and physiognomic gradients of woody plants in a semi-arid African savanna woodland. - Plant Ecol. 124: 9-23.

[52] Wolda, H. (1981): Similarity indices, sample size and diversity. - Oecologia 50: 296-302.

[53] Yaseen, G., Ahmad, M., Sultana, S., Alharrasi, A. S., Hussain, J., Zafar, M. (2015): Ethnobotany of medicinal plants in the Thar Desert (Sindh) of Pakistan. - J. Ethnopharmacol. 163: 43-59. 